\title{
Determination of colistin resistance in Escherichia coli isolates from foods in Turkey, 2011-2015
}

\author{
Mustafa Güzel $^{1 \oplus}$, M. Dilek Avşaroğlu' ${ }^{2}$, Yeşim Soyer $^{3}{ }^{\circledR}$
}

Cite this article as:

Güzel, M., Avşaroğlu, M.D., Soyer, Y. (2020). Determination of colistin resistance in Escherichia coli isolates from foods in Turkey. Food and Health, 6(3), 160-169. https://doi.org/10.3153/FH20017

${ }^{1}$ Hitit University, Faculty of Engineering, Department of Food Engineering, Çorum, Turkey

${ }^{2}$ Ahi Evran University, Faculty of Agriculture, Department of Agricultural Biotechnology, Kırşehir, Turkey

${ }^{3}$ Middle East Technical University, Faculty of Engineering, Department of Food Engineering, Ankara, Turkey

\section{ORCID IDs of the authors:}

M.G. 0000-0002-4750-7488

M.D.A. 0000-0002-3106-9209

Y.S. 0000-0001-9687-9715

Submitted: 15.11 .2019

Revision requested: 09.02 .2020

Last revision received: 21.02 .2020

Accepted: 07.03.2020

Published online: 16.05 .2020

Correspondence: Yeşim SOYER

E-mail: ysoyer@metu.edu.tr

\begin{abstract}
Antimicrobial resistance of pathogenic microorganisms is an emerging public health concern. Intensive use of antibiotics in food animals might increase antimicrobial resistance in foodborne pathogens. Colistin is a last resort antibiotic for treatment of multidrug resistant (MDR) Gram negative pathogens. The recent antimicrobial resistance studies revealed a mobile antimicrobial resistance gene $(\mathrm{mcr})$ that provides resistance to colistin. Furthermore, the gene has been found in different genera. Therefore, the aim of this study was to determine colistin resistance of Escherichia coli isolates $(\mathrm{N}=48)$ isolated in between 2011 and 2015 from food samples in Turkey. In addition, $5 \mathrm{mcr}$ genes and their variants were screened by performing PCR on resistant isolates. $4 \mathrm{E}$. coli isolates were found resistant to colistin above the epidemiological cut-off value (Minimum inhibitory concentration (MIC) $>2 \mathrm{mg} / \mathrm{L}$ ). None of the resistant isolates had the $\mathrm{mcr}$ genes. Further studies with human and food isolates should be conducted to figure out which gene or genes are responsible for colistin resistance.
\end{abstract}

Keywords: Antimicrobial resistance, Colistin, Escherichia coli

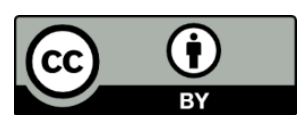

CCopyright 2020 by ScientificWebJournals Available online at 


\section{Introduction}

Antimicrobial resistance is one of the main public health concerns. Ineffective antibiotics might mean longer treatment, even death in some cases such as cancer treatment, organ transplant, surgeries, and dialysis (CDC, 2013). In the United States (US), more than two million of drug resistant case occurred, results in 23000 deaths, annually (CDC, 2013). It was estimated that the economic cost of drug resistant infections was around 35 billion dollars (CDC, 2013). One of the main reasons of antimicrobial resistance is to overuse of antibiotics in farm animals.

Colistin is a last resort antibiotic due to its nephrotoxic effect for humans. It is mainly used against MDR Gram negative infections (Ordooei et al., 2015). A pathogen is considered as MDR when it is resistant to 3 or more antibiotics (Tang et al., 2017). Colistin is also used in veterinary medicine to treat animal digestive disorders. Before the study of Liu et al. (2016), it was believed that colistin resistance occurred through chromosomal mutations, and thus, was only transferred vertically. However, Liu et al. (2016) discovered a transferrable, plasmid mediated gene $(\mathrm{mcr}-1)$ that causes colistin resistance in E. coli. The gene was dated back to mid 2000's and most likely spread from farm animals in China (Wang et al., 2018a).

After the identification of the gene, a number of reports showed that $m c r-1$ has already spread globally, from South America (Arcilla et al., 2016; Fernandes et al., 2016), North America (McGann et al., 2016; Mulvey et al., 2016), Africa (Olaitan., 2016), to Japan (Suzuki et al., 2016) and South Asia (Tse and Yuen, 2016). Plasmid mediated colistin resistance has been found in almost all of the European countries (Campos et al., 2016; Doumith et al., 2016; Falgenhauer et al., 2016; Malhotra-Kumar et al., 2016; Prim et al., 2016; Zurfuh et al., 2016).

Although $m c r-1$ gene has dominantly been found in $E$. coli (Arcilla et al., 2016), the gene was also identified in different species such as; Enterobacter aerogenes (Zeng et al., 2016), Enterobacter cloacae (Zeng et al., 2016), Citrobacter freundii (Li et al., 2017), Citrobacter braakii (Sennati et al., 2017), Klebsiella pneumonia (Liu et al., 2016), and Salmonella enterica (Webb et al., 2016). In addition, resistant isolates found in poultry, cattle (Hu et al., 2016), fowl (Yang et al., 2018), turkey, and pigs (Perrin-Guyomard et al., 2016) as well as environmental samples (Zurfuh et al., 2016). What is more, $m c r-1$ was found in a number of different plasmid replicon types, which further contributes the dissemination of resistance (Wang et al., 2018b; Ye et al., 2016).

Recently, several variants of $m c r-1$, which were also provide resistance to colistin, were discovered. One of the genes, $\mathrm{mcr}$ -
2, was found in Belgium (Xavier et al., 2016). The gene was on a $35 \mathrm{k}$ base plasmid, and was more prevalent than $m c r-1$ in colistin resistant bacteria. It was also reported that the plasmid harboring $m c r-2$ has a higher conjugation rate than original $m c r-1$ harboring plasmid (Xavier et al., 2016). Yin et al. (2017) reported the discovery of $m c r-3$, another plasmid encoded colistin resistance variant of $m c r-1$. After the first report, $m c r-3$ gene was found in Salmonella isolates from human patients in Denmark (Litrup et al., 2017; Roer et al., 2017), and E. coli isolates from cattle in Spain (Hernandez et al., 2017). In both studies, there were isolates carried both $m c r-1$ and $m c r-3$ gene. Soon after the discovery of $m c r-3$, Carattoli et al. (2017) were discovered the existence of $\mathrm{mcr}$ 4 in Salmonella and E. coli isolates. The gene was found in pathogens that were isolated in Italy, in Spain, and in Belgium in a time frame between 2013 to 2016 (Carattoli et al., 2017). Borowiak et al. (2017) defined a transposon associated resistance gene, $m c r-5$, in Salmonella Paratyphi B. Yang et al. (2016) identified $m c r-7$ in a IncI2 type plasmid in a K. pneumoniae isolate, in China. Wang et al. (2018) discovered mcr8 in NDM producing K. pneumoniae. Lastly, $m c r-9$ was identified in a Salmonella Typhimurium, in the US (Carroll et al., 2019). To date, more than $40 \mathrm{mcr}$ genes and variants has been described. Additionally, co-occurrence of different $m c r$ genes has been reported in several studies (Garcia et al., 2018; Hernandez et al., 2017; Yang et al., 2016).

Studies showed the animal to human transmission of $\mathrm{mcr}-1$ (Hasman et al., 2016; Liu et al., 2016; Ye et al., 2016). Considering the rapid dissemination of the gene and the importance of colistin in medicine, public health implications are severe. Therefore, the purpose of this study was to determine the colistin resistance, and to investigate the existence of $m c r-1$ to $m c r-5$ genes and their variants by screening the $E$. coli strains previously isolated from food samples collected in Van and Ankara, Turkey.

\section{Materials and Methods}

In this study, $48 E$. coli strains that were isolated in between 2011-2015 from foods in previous studies, were screened (Table 1). Detailed description of Van samples was given by Kyere et al. (2015).

\section{Isolation and Conformation of E. coli}

A total of 28 samples were isolated in Van, 2011, and the rest were isolated in Ankara (n:20), 2015. E. coli isolates had been held in $-80^{\circ} \mathrm{C}$ prior the experiments, and was a part of METU Food Safety Lab collection. In both experiments, subsampling and isolation were performed following the $E$. coli isolation method of the Food and Drug Administration (FDA) (Feng et al., 2011). 
Table 1. Van E. coli isolates, their sources, isolation locations, and phenotypic resistances

\begin{tabular}{|c|c|c|c|}
\hline METU IDs & $\begin{array}{l}\text { Specific } \\
\text { source }\end{array}$ & City Collected & Antibiotics resistant to \\
\hline MET-K1-001 & Raw milk & Van & NR \\
\hline MET-K1-002 & Herby Cheese & Van & NR \\
\hline MET-K1-003 & Raw milk & Van & Gentamycin \\
\hline MET-K1-004* & Raw milk & Van & NR \\
\hline MET-K1-005 & Raw milk & Van & NR \\
\hline MET-K1-006 & Raw patty meat & Van & NR \\
\hline MET-K1-007 & Chicken wings & Van & AMP, FOX, NA \\
\hline MET-K1-008 & Salted cheese & Van & NR \\
\hline MET-K1-009 & Chicken drumstick & Van & AMP, AMC, SF, SXT, TE, CN, S \\
\hline MET-K1-010 & Chicken drumstick & Van & AMP, AMC, SF, SXT, TE, CN, S \\
\hline MET-K1-011 & Chicken drumstick & Van & AMP, SF, SXT, NA, TE, CN, S \\
\hline MET-K1-012 & Turkey wings & Van & AMP, TE \\
\hline MET-K1-013 & Chicken drumstick & Van & NR \\
\hline MET-K1-014* & Chicken drumstick & Van & AMC, SF, SXT, NA, TE, S, K \\
\hline MET-K1-015* & Chicken drumstick & Van & AMP, AMC, SF, SXT, NA, TE, S \\
\hline MET-K1-016 & Chicken drumstick & Van & AMP, AMC, SF, SXT, NA, TE, S \\
\hline MET-K1-017 & Chicken drumstick & Van & AMP, AMC, SF, SXT, NA, TE \\
\hline MET-K1-018 & Chicken drumstick & Van & AMP, SF, SXT, NA, TE, S, K, C \\
\hline MET-K1-019 & Chicken drumstick & Van & AMP, KF, SF, SXT, NA, TE, CN, C \\
\hline MET-K1-020 & Chicken drumstick & Van & NR \\
\hline MET-K1-021 & Chicken drumstick & Van & AMP, SF, SXT, TE, S \\
\hline MET-K1-022 & Chicken drumstick & Van & AMP, KF, SF, SXT, NA, TE, S, K, C \\
\hline MET-K1-023 & Raw milk & Van & NR \\
\hline MET-K1-024* & Herby cheese & Van & AMP, AMC, SF, NA, TE, S, C \\
\hline MET-K1-025 & Chicken drumstick & Van & AMP \\
\hline MET-K1-026 & Herby cheese & Van & NR \\
\hline MET-K1-027 & Raw milk & Van & NR \\
\hline MET-K1-028 & Chicken drumstick & Van & AMP, SF, S, C \\
\hline
\end{tabular}

* Strains that exhibited colistin resistance.

AMP: Ampicillin, AMC: Amoxycillin/Clavulanic Acid, SF: Sulfafurazole, SXT: Sulphamethoxazole/Trimethoprim, TE: Tetracycline, S: Streptomycin, K: Kanamycin, C: Chloramphenicol Cro: Ceftriaxone, Eft: Ceftiofur, , Imp: Imipenem, Ak: Amikacin, Cn: Gentamicin, , Cip: Ciprofloxacin, N: Nalidixic acid, Fox: Cefoxitin, Kf: Cephalothin, Etp: Ertapenem, NR: Not resistant

Briefly, food samples were collected from the markets in city center of Van and Ankara, for E. coli isolation (Table 1). The samples then were transferred to the laboratory at the Food Engineering Department of Yuzuncu Yil University in Van and Food Engineering Department of METU. $25 \mathrm{~g}$ of each food sample was weighted aseptically, and was transferred to $225 \mathrm{~mL}$ of buffered peptone water for enrichment of E. coli, followed by homogenization using a stomacher. Homogenates were incubated at $36^{\circ} \mathrm{C}$ for $18 \mathrm{~h}$ for cell enrichment, then $20 \mu \mathrm{L}$ of each homogenate was sub-cultured on Endo Agar. After $18-24 \mathrm{~h}$ of incubation at $36^{\circ} \mathrm{C}$ in an incubator, suspected colonies were isolated for further confirmation. In case of Van samples, suspected $E$. coli isolates were stored at $-20^{\circ} \mathrm{C}$ in brain heart infusion (BHI) broth with $15 \%(\mathrm{v} / \mathrm{v})$ glycerol prior to transport to the Food Engineering Department at Middle East Technical University (METU), Ankara, Turkey.

\section{Determination of Antimicrobial Resistance}

The existence of $m c r-1$ to $m c r-5$ in the isolates were carried out in two steps. Initially, phenotypic colistin resistance of $E$. coli isolates was determined by MIC. Then borderline susceptible and resistance isolates was screened by PCR for the 
existence of $m c r-1, m c r-2, m c r-3, m c r-4, m c r-5$ genes (Rebelo et al., 2018).

\section{Phenotypic Characterization of Antimicrobial Resistance}

MIC testing was conducted with broth dilution method based on CLSI standards and EUCAST criteria (CLSI, 2014; EUCAST, 2016). For this, series of concentrations of colistin were prepared from commercial lyophilized colistin sulphate (Sigma-Aldrich), and added to the cation adjusted Muller Hilton Broth (CAMHB) in the test tubes, respectively. To standardize the inoculum density, 0.5 McFarland standard was used as turbidity standard. For every test, negative control (without antibiotic) was prepared.

\section{PCR Screening for mor Genes}

After the MIC testing, isolates with $2 \mathrm{mg} / \mathrm{L}$ or higher colistin resistance was checked for $m c r-1$ to $m c r-5$ genes. PCR analysis was done described by Rebelo et al. (2018) by using the primers $m c r-1-\mathrm{F}\left(5^{\prime}\right.$-GGCACCAGTATTGGCCTGCT-3'), $m c r-1$-R (5'- CATATGCGCCACAATGTGTTG -3'), $m c r-2-F$ (CAAGTGTGTTGGTCGCAGTT), $m c r-2-R$ (TCTAGCCCGACAAGCATACC), mcr-3-F (AAATAAAAATTGTTCCGCTTATG), $m c r-3-R$ (AATGGAGATCCCCGTTTTT), mcr-4-F (TCACTTTCATCACTGCGTTG), $m c r-4-R$ (TTGGTCCATGACTACCAATG) $m c r-5-F$ (ATGCGGTTGTCTGCATTTATC), $m c r-5-R$ (TCATTGTGGTTGTCCTTTTCTG). E. coli NTCC 13846 strain was used as positive control for $m c r-1$ gene.

Conditions of PCR was as follows; $94{ }^{\circ} \mathrm{C}$ for 15 minutes for initial denaturation, $94{ }^{\circ} \mathrm{C}$ for 30 seconds, $58{ }^{\circ} \mathrm{C}$ for $90 \mathrm{sec}-$ onds, $72{ }^{\circ} \mathrm{C}$ for 60 seconds for 25 cycle, and a final elongation at $72{ }^{\circ} \mathrm{C}$ for 10 minutes. Samples were taken from Eppendorf tubes, placed into gel, and ran in electrophoresis for 45 minutes. The gel was placed into staining-bath contains Ethidium Bromide solution for 30 minutes, rinsed in water, and visualized in BioRad Molecular Imager Gel-Dox XR.

\section{Results and Discussion}

In total, 48 E. coli strains isolated from various sources in two different cities were tested. 20 samples were isolated from poultry in Ankara, 2015. Rest of the samples were isolated from various sources (17 poultry, 6 raw milk, 4 cheese, and 1 meat) in Van, 2011 (Table 1) (Kyere et al., 2015). 11 samples were susceptible to antibiotics. Two samples were resistant to one antibiotic while the rest of the samples showed multi-resistance of two or more antibiotics. Furthermore, three of the samples were resistant to eight antibiotics. All resistant isolates were collected from food samples and were non-pathogenic. Van isolates were discussed in detail by Kyere et al. (2015). Unlike Van isolates, only three of the Ankara isolates were susceptible to antibiotics, phenotypically (Table 2). The rest were resistant to two or more antibiotics. Furthermore, 10 of the isolates were resistant to five or more antibiotics. Antibiotic resistance of Ankara isolates further characterized with PCR screening of antibiotic resistance genes. Majority of the isolates carried more than one antibiotic resistance gene (Table 3). Nine of the Ankara isolates carried Extended Spectrum $\beta$-Lactamase (bla TEM1 $_{1}$ ) gene. Although three isolates showed phenotypic resistance, resistance genes could not been determined.

MIC results revealed that 4 isolates were resistant to colistin (MIC $\geq 2 \mathrm{mg} / \mathrm{L}$ ) (Table 4). 3 of these isolates were resistant to at least two more antibiotics. All of the colistin resistant samples were isolated in Van, 2011. Among them two of the samples were isolated from dairy product (one cheese and one raw milk), the other two were isolated from poultry products. However, PCR screening of isolates for $\mathrm{mcr}$ genes were negative. The results implied that resistant isolates had a different resistance mechanism (e.g. vertical gene transfer) than plasmid mediated resistance. Another possible explanation might be the existence of other $m c r$ genes. In this study, we screened samples only for $m c r-1$ to $m c r-5$. However, there are 4 more $m c r$ genes $m c r-6, m c r-7, m c r-8, m c r-9$, and their variants confer colistin resistance. Previous studies showed that currently ratio of plasmid mediated colistin resistance, due to $m \mathrm{cr}-1$, is relatively low. For example, El Garch et al. (2017), reported that only 45 of 292 colistin resistant isolates had the $m c r-1$ gene. Negative results might be associated with this low ratio.

Although $m c r$ genes and their variants has already spread to the ecosystem, prevalence of $m c r-1$ in food samples relatively low compared to wastewater and animal feces. Chen et al. (2017) reported the prevalence of $m c r-1$ gene in colistin resistant bacteria from food samples as $36 \%$, while the prevalence of $m c r-1$ was $51 \%$ and $71 \%$ in animal feces and water, respectively. This difference might be due to the variety of gene acquisition mechanisms. For example, while plasmids that carry $m c r-1$ in Salmonella food isolates were conjugative, plasmids in Salmonella animal isolates were not. It was suggested that $m c r-1$ acquisition in food Salmonella isolates probably due to a cross species conjugation from $E$. coli, instead of Salmonella animal samples (Cui et al., 2017). 
Table 2. Ankara E. coli isolates, their sources, isolation locations, and phenotypic resistances

\begin{tabular}{llll}
\hline METU IDs & Specific food source & City Collected & Antibiotics resistant to \\
\hline MET A1-001 & Chicken Breast & Ankara & CRO, EFT, AMP, AMC, FOX, KF \\
MET A1-002 & Chicken Thigh & Ankara & AMP, AMC, FOX, KF \\
MET A1-003 & Chicken Wing & Ankara & SF, SXT, C, CN, K, S, CIP, N, AMP, T \\
MET A1-004 & Chicken Thigh & Ankara & CIP, N \\
MET A1-005 & Chicken Thigh & Ankara & SF, SXT CN, K, CIP, N, AMP, T \\
MET A1-007 & Chicken Wing & Ankara & S, AMP, KF \\
MET A1-008 & Chicken Breast & Ankara & SF, SXT, C, K, S, CIP, N, AMP, T, KF \\
MET A1-009 & Chicken Rib & Ankara & KF \\
MET A1-010 & Chicken Wing & Ankara & SF, SXT, C, CN, S, CIP, N, AMP, T \\
MET A1-011 & Chicken Wing & Ankara & SF, S, CIP, N, T \\
MET A1-012 & Chicken Wing & Ankara & SF, K, CIP, N, T \\
MET A1-014 & Chicken Wing & Ankara & NR \\
MET A1-015 & Chicken Thigh & Ankara & SF, SXT, C, S, CIP, N, AMP, T \\
MET A1-016 & Chicken Wing & Ankara & SF, SXT, C, CN, S, CIP, N, AMP, T, KF \\
MET A1-017 & Chicken Rib & Ankara & NR \\
MET A1-018 & Chicken Thigh & Ankara & NR \\
MET A1-019 & Chicken Wing & Ankara & SF, SXT, C, K, S, CIP, N, AMP. T, KF \\
MET A1-020 & Chicken Thigh & Ankara & SF, T \\
MET A1-021 & Chicken Thigh & Ankara & CIP, N, ETP \\
\hline AMP A A
\end{tabular}

AMP: Ampicillin, AMC: Amoxycillin/Clavulanic Acid, SF: Sulfafurazole, SXT: Sulphamethoxazole/Trimethoprim, TE: Tetracycline, S: Streptomycin, K: Kanamycin, C: Chloramphenicol Cro: Ceftriaxone, Eft: Ceftiofur, Imp: Imipenem, Ak: Amikacin, Cn: Gentamicin, , Cip: Ciprofloxacin, N: Nalidixic acid, Fox: Cefoxitin, Kf: Cephalothin, Etp: Ertapenem, NR: Not resistant

Table 3. Specific source and resistance profiles of E. coli, isolated in Ankara, 2015

\begin{tabular}{|c|c|c|c|}
\hline Isolate ID & $\begin{array}{l}\text { Specific } \\
\text { Source } \\
\end{array}$ & Phenotypic Resistance & Resistance genes \\
\hline MET A1-001 & Chicken Breast & CroEftAmpAmcFoxKf & bla $a_{\mathrm{CMY}-2}$ \\
\hline MET A1-002 & Chicken Thigh & AmpAmcFoxKf & $\mathrm{ND}$ \\
\hline MET A1-003 & Chicken Wing & SfSxtCCnKSCipNAmpT & bla $a_{\mathrm{TEM}-1,}$ flo, aadA1, aadA2, aphA1-Iab, dhfrI, tetA, sull \\
\hline MET A1-004 & Chicken Thigh & CipN & ND \\
\hline MET A1-005 & Chicken Thigh & SfSxtCnKCipNAmpT & 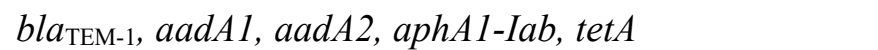 \\
\hline MET A1-007 & Chicken Wing & SAmpKf & bla $\mathrm{TEM}-1,_{1}$ aadA1 \\
\hline MET A1-008 & Chicken Breast & SfSxtCKSCipNAmpTKf & bla $a_{\mathrm{TEM}-1}$, cat 1, aphA1-Iab \\
\hline MET A1-009 & Chicken Rib & $\mathrm{Kf}$ & ND \\
\hline MET A1-010 & Chicken Wing & SfSxtCCnSCipNAmpT & bla $a_{\mathrm{TEM}-1}$, flo, aadA1, dhfrI, tetA, sull \\
\hline MET A1-011 & Chicken Wing & SfSCipNT & tetA \\
\hline MET A1-012 & Chicken Wing & SfKCipNT & aadA1, aadA2, tetA \\
\hline MET A1-014 & Chicken Wing & Susceptible & aadA2 \\
\hline MET A1-015 & Chicken Thigh & SfSxtCSCipNAmpT & bla ${ }_{T E M-1}$, flo, aadA1, aphA1-Iab, tetA, aadA2, sul1 \\
\hline MET A1-016 & Chicken Wing & SfSxtCCnSCipNAmpTKf & flo, aadA1, aphA1-Iab, dhfrI, tetA, sul1 \\
\hline MET A1-017 & Chicken Rib & Susceptible & bla $_{T E M-1}$ \\
\hline MET A1-018 & Chicken Thigh & Susceptible & bla \\
\hline MET A1-019 & Chicken Wing & SfSxtCKSCipNAmpTKf & bla ${ }_{C M Y-2}$, cat 1 \\
\hline MET A1-020 & Chicken Thigh & SfT & tet $A$ \\
\hline MET A1-021 & Chicken Thigh & CipNEtp & bla $a_{\mathrm{TEM}-1,}$, adA 2 \\
\hline
\end{tabular}
Cro: Ceftriaxone, Eft: Ceftiofur, Sf: Sulfafurazole, Sxt: Sulphamethaxazole/trimethoprim, C: Chloramphenicol, Imp: Imipenem, Ak: Amikacin, Cn: Gentamicin, K: Kanamycin, S: Streptomycin, Cip: Ciprofloxacin, N: Nalidixic acid, Amp: Ampicillin, Amc: Amoxicillin-clavulanic acid, T: Tetracycline, Fox: Cefoxitin, Kf: Cephalothin, Etp: Ertapenem, ND: Not determined 
Table 4. Colistin resistant E. coli isolates, their sources, other resistances, and MIC values

\begin{tabular}{llll}
\hline Isolate ID & Specific Source & Antibiotics resistant to & MIC \\
\hline MET-K1-004 & Raw milk & Susceptible & $\geq 2 \mathrm{mg} / \mathrm{L}$ \\
MET-K1-014 & Chicken drumstick & AMC, SF, SXT, NA, TE, S, and K. & $\geq 2 \mathrm{mg} / \mathrm{L}$ \\
MET-K1-015 & Chicken drumstick & AMP, AMC, SF, SXT, NA, TE, and S. & $\geq 2 \mathrm{mg} / \mathrm{L}$ \\
MET-K1-024 & Herby cheese & AMP, AMC, SF, NA, TE, S, and C. & $\geq 2 \mathrm{mg} / \mathrm{L}$ \\
\hline
\end{tabular}

AMP: Ampicillin, AMC: Amoxycillin/Clavulanic Acid, SF: Sulfafurazole, SXT: Sulphamethoxazole/Trimethoprim, TE: Tetracycline, S: Streptomycin, NA: Nalidixic Acid, K: Kanamycin, C: Chloramphenicol

Nearly all plasmid mediated colistin studies showed that resistant isolates had multidrug resistance (MDR) including Extended Spectrum $\beta$-Lactamase (bla $a_{\mathrm{ESBL}}, b a_{\mathrm{CTX}-\mathrm{M}-15}, b l a_{\mathrm{CTX}}-$ M-55, bla $a_{\mathrm{TEM} 1}$ ) (Li et al., 2016; Zeng et al., 2016; Zurfuh et al., 2016), Carbapanemases (Sun et al., 2016), and New Delhi Metallo $\beta$-Lactamase (bla $a_{\mathrm{NDM}-5}$, bla $a_{\mathrm{NDM}-9}$ ) (Borowiak et al., 2017; Yao et al., 2016). While our multidrug resistant isolates did not have $m c r$ genes, the reports highlight the possible significant challenge in treatment of MDR infections.

\section{Conclusion}

MDR pathogens can be associated with increased treatment durations to life threatening conditions. There are currently a few antibiotics deployed against MDR infections. Colistin is a last line of defense against MDR Gram negative pathogens. Plasmid mediated colistin resistance disseminated rapidly between the several sources, bacterial species and continents. The absence of colistin treatment might have severe consequences. Previous studies showed the importance of farm animals and foods as gene transfer media. As a result, studies should focus on reducing the unnecessary antibiotic usage, and alternative treatments, especially in veterinary medicine.

Foodborne pathogen infections are still a serious threat for human health. In this regard, antibiotic resistance of foodborne pathogens is a critical concern. Colistin has been used for treatment of farm animals across all European countries. Considering the fact that plasmid mediated colistin resistance has spread globally, our results do not show or imply that $\mathrm{mcr}$ genes was not present in Van and Ankara, Turkey. Further studies with more isolates should be conducted. More sources such as hospitals, wastewater, and poultry farms should be monitored.

\section{Compliance with Ethical Standard}

Conflict of interests: The authors declare that for this article they have no actual, potential or perceived the conflict of interests.

Ethics committee approval: Author declare that this study does not include any experiments with human or animal subjects.
Funding disclosure: -

Acknowledgments: -

\section{References}

Arcilla, M.S., van Hattem, J.M., Matamoros, S., Melles, D.C., Penders, J., de Jong, M.D., Schultsz, C. (2016). Dissemination of the mcr-1 colistin resistance gene. The Lancet Infectious Diseases, 16(2), 147-149. https://doi.org/10.1016/S1473-3099(15)00541-1

Borowiak, M., Fischer, J., Hammer, J.A., Hendriksen, R.S., Szabo, I., Malorny, B. (2017). Identification of a novel transposon-associated phosphoethanolamine transferase gene, mcr-5, conferring colistin resistance in d-tartrate fermenting Salmonella enterica subsp. enterica serovar Paratyphi B. Journal of Antimicrobial Chemotherapy, 72(12), 3317-3324.

https://doi.org/10.1093/jac/dkx327

Carattoli, A., Villa, L., Feudi, C., Curcio, L., Orsini, S., Luppi, A., Pezzotti, G., Magistrali, C.F. (2017). Novel plasmid-mediated colistin resistance mcr-4 gene in Salmonella and Escherichia coli, Italy 2013, Spain and Belgium, 2015 to 2016. Eurosurveillance, 22(31), 30589.

https://doi.org/10.2807/1560-7917.ES.2017.22.31.30589

Carroll, L.M., Gaballa, A., Guldimann, C., Sullivan, G., Henderson, L.O., Wiedmann, M. (2019). Identification of novel mobilized colistin resistance gene mor-9 in a multidrug-resistant, colistin-susceptible Salmonella enterica serotype Typhimurium isolate. mBio, 10(3), e00853-19.

https://doi.org/10.1128/mBio.00853-19

Centers for Disease Control and Prevention (CDC). (2013). Antibiotic resistance threats in the United States. 
http://www.cdc.gov/drugresistance/threat-report2013/pdf/ar-threats-2013-508.pdf (accessed 11/21/2018).

Chen, K., Chan, E.W.C., Xe, M,. Ye, L., Dong, N., Chen, S. (2017). Widespread distribution of mcr-1-bearing bacteria in the ecosystem, 2015 to 2016. Eurosurveillance, 22(39), 1700206.

https://doi.org/10.2807/1560-7917.ES.2017.22.39.17-00206

Clinical and Laboratory Standards Institute (CLSI) (2014). Performance standards for antimicrobial susceptibility testing; Twenty-fourth informational supplement. CLSI document M100-S24. Clinical and Laboratory Standards Institute Wayne, PA.

Cui, M., Zhang, J., Zhang, C., Li, R., Chan, E.W., Wu, C., Wu, C., Chen, S. (2017). Distinct mechanisms of acquisition of mcr-1 -bearing plasmid by Salmonella strains recovered from animals and food samples. Scientific Reports, 7, 13199. https://doi.org/10.1038/s41598-017-01810-4

Doumith, M., Godbole, G.A., Philip, L., Lesley, D., Tim, D., Martin, D., Michaela, M-P., Berit, E., Matthew, J de P, Elizabeth, J., Alan, P.H., Katie, L.W. (2016). Detection of the plasmid-mediated mcr-1 gene conferring colistin resistance in human and food isolates of Salmonella enterica and Escherichia coli in England and Wales. Journal of Antimicrobial Chemotherapy, 71(8), 2300-2305.

https://doi.org/10.1093/jac/dkw093

El Garch, F., Sauget, M., Hocquet, D., LeChaudee, D., Woehrle, F., Bertrand, X. (2017). mcr-1is borne by highly diverse Escherichia coli isolates since 2004 in food-producing animals in Europe. Clinical Microbiology and Infection, 23(1), 51.e1-51.e4.

https://doi.org/10.1016/j.cmi.2016.08.033

European Committee on Antimicrobial Susceptibility Testing (EUCAST) (2016). Recomendations for MIC determination colistin (polymixin E) Eucast.org, http://www.eucast.org/fileadmin/src/media/PDFs/EUCAST files/General documents/Recommendations for MIC determination_of_colistin_March_2016.pdf(accessed 29 March 2016).

Falgenhauer, L., Waezsada, S-E., Yao, Y., Imirzalioglu, C., Käsbohrer, A., Roesler, U., Michael, G.B., Schwarz,
S., Werner, G., Kreienbrock, L., Chakraborty, T. (2016). Colistin resistance gene mcr-1 in extended-spectrum $\beta$-lactamase-producing and carbapenemase-producing Gram-negative bacteria in Germany. The Lancet Infectious Diseases, 16(3), 282-283.

https://doi.org/10.1016/S1473-3099(16)00009-8

Feng, P., Weagant, S.D., Jinneman, K. (2011). BAM: diarrheagenic Escherichia coli. Silver Spring (MD), United States Food and Drug Administration.

https://www.fda.gov/food/laboratory-methods-food/bam-diarrheagenic-escherichia-coli (accessed 11/21/2018).

Fernandes, M.R., McCulloch, J.A., Vianello, M.A., Moura, Q., Pérez-Chaparro, P.J., Esposito, F., Lincopan, N. (2016). First report of the globally disseminated IncX4 plasmid carrying the mcr-1 gene in a colistin-resistant Escherichia coli sequence type 101 isolate from a human infection in Brazil. Antimicrobial Agents and Chemotherapy, 60, 64156417.

https://doi.org/10.1128/AAC.01325-16

García, V., García-Meniño, I., Mora, A., Flament-Simon, S.C., Díaz-Jiménez, D., Blanco, J.E., Blanco, J. (2018). Cooccurrence of mcr-1, mcr-4 and mcr-5 genes in multidrugresistant ST10 Enterotoxigenic and Shiga toxin-producing Escherichia coli in Spain (2006-2017). International Journal of Antimicrobial Agents, 52(1), 104-108.

https://doi.org/10.1016/j.ijantimicag.2018.03.022

Hasman, H., Hammerum, A.M., Hansen, F., Hendriksen, R.S., Olesen, B., Agerso, Y., Zankari, E., Leekitchharoenphon, P., Stegger, M., Kaas, R.S., Cavaco, L.M., Hansen D.S., Aarestrup, F.M., Skov, R.L. (2015). Detection of mcr-1 encoding plasmid mediated colistin resistant Escherischia coli isolates from human bloodstream infection and imported chicken meat, Denmark 2015. Eurosurveillance, 20(49), 1-5.

https://doi.org/10.2807/1560-7917.ES.2015.20.49.30085

Hernández, M., Iglesias, M.R., Rodríguez-Lázaro, D., Gallardo, A., Quijada, N.M., Miguela-Villoldo, P., Campos, M.J., Píriz, S., López-Orozco, G., de Frutos, C, Sáez, J.L., Ugarte-Ruiz, M., Domínguez, L., Quesada, A. (2017). Co-occurrence of colistin-resistance genes mcr-1 and mcr-3 
among multidrug-resistant Escherichia coli isolated from cattle, Spain, September 2015. Eurosurveillance, 22(31), pii $=30586$.

https://doi.org/10.2807/1560-7917.ES.2017.22.31.30586

Hu, Y., Liu, F., Lin, I.Y.C., Gao, G.F., Zhu, B. (2016). Dissemination of the mcr-1 colistin resistance gene. The Lancet Infectious Diseases, 16(2), 146-147.

https://doi.org/10.1016/S1473-3099(15)00533-2

Kyere, E.O, Bulut, E., Avşaroğlu, M.D., Soyer, Y. (2015). Molecular evaluation and antimicrobial susceptibility testing of Escherichia coli isolates from food products in Turkey. Food Science and Biotechnology, 24(3), 1001-1009. https://doi.org/10.1007/s10068-015-0128-6

Li, A., Yang, Y., Miao, M., Chavda, K.D., Xie, X., Feng, P., Tang, Y. (2016). Complete sequences of mcr-1-Harboring plasmids from extended spectrum b-lactamase and carbapenemase producing Enterobacteriaceae. Antimicrobial Agents and Chemotherapy, 60(7), 4351-4354.

https://doi.org/10.1128/AAC.00550-16

Li, X.P., Fang, L.X., Jiang, P., Pan, D., Xia, J., Liao, X.P., Sun, J. (2017). Emergence of the colistin resistance gene mcr-1 in Citrobacter freundii. International Journal of Antimicrobial Agents, 49(6), 786-787.

https://doi.org/10.1016/j.ijantimicag.2017.04.004

Litrup, E., Kiil, K., Hammerum, A.M., Roer, L., Nielsen, E.M., Torpdahl, M. (2017). Plasmid-borne colistin resistance gene mcr-3 in Salmonella isolates from human infections, Denmark, 2009-17. Eurosurveillance, 22(31), pii $=30587$.

https://doi.org/10.2807/1560-7917.ES.2017.22.31.30587

Liu, Y.-Y., Wang, Y., Walsh, T.R., Yi, L.X., Zhang, R., Spencer, J., Doi, Y., Tian, G., Dong, B., Huang, X., Yu, L.F., Gu, D., Ren, H., Chen, X., Lv, L., He, D., Zhou, H., Liang, Z., Liu, J.H., Shen, J. (2016). Emergence of plasmidmediated colistin resistance mechanism mor-1 in animals and human beings in China: a microbiological and molecular biological study. The Lancet Infectious Diseases, 16(2), 161168.

https://doi.org/10.1016/S1473-3099(15)00424-7
Malhotra-Kumar, S., Xavier, B.B., Das A.J., Lammens, C., Butaye, P., Goossens, H. (2016). Colistin resistance gene mcr-1 harboured on a multidrug resistant plasmid. The Lancet Infectious Diseases, 16(3), 283-284.

https://doi.org/10.1016/S1473-3099(16)00012-8

McGann P, Snesrud E, Maybank R, Corey B, Ong AC, Clifford R, Hinkle M, Whitman T, Lesho E, Schaecher KE. (2016). Escherichia coli harboring mor-1 and blaCTX$\mathrm{M}$ on a novel IncF plasmid: First report of mcr-1 in the USA. Antimicrobial agents and Chemotherapy, 60(7), 4420-4421. https://doi.org/10.1128/AAC.01103-16

Mulvey, M.R., Matajese, L.F., Robertson, J., Nash, J.H.E., Boerlin, P., Toye, B., Irwin, R., Melano, R.G. (2016). Dissemination of the mcr-1 colistin resistance gene. The Lancet Infectious Diseases, 16(3), 289-290.

https://doi.org/10.1016/S1473-3099(16)00067-0

Olaitan AO, Chabou S, Okdah L, Morand S, Rolain JM. (2016). Dissemination of the mcr-1 colistin resistance gene. The Lancet Infectious Diseases, 16(2), 147.

https://doi.org/10.1016/S1473-3099(15)00540-X

Ordooei, J.A., Shokouhi, S., Sahraei, Z. (2015). A review on colistin nephrotoxicity. European Journal of Clinical Pharmacology, 71(7), 801-810.

https://doi.org/10.1007/s00228-015-1865-4

Perrin-Guyomard, A., Bruneau, M., Houée, P., Deleurme, K., Legrandois, P., Poirier, C., Soumet, C., Sanders, P. (2016). Prevalence of mcr-1 in commensal Escherichia coli from French livestock, 2007 to 2014. Eurosurveillance, 21(6); pii=30135.

https://doi.org/10.2807/1560-7917.ES.2016.21.6.30135

Prim, N., Rivera, A., Rodríguez-Navarro, J., Español, M., Turbau, M., Coll, P., Mirelis, B. (2016). Detection of mcr1 colistin resistance gene in polyclonal Escherichia coli isolates in Barcelona, Spain, 2012 to 2015. Eurosurveillance, 21(13), pii=30183.

https://doi.org/10.2807/1560-7917.ES.2016.21.13.30183

Rebelo, A.R., Bortolaia, V., Kjeldgaard, J.S., Pedersen, S.K., Leekitcharoenphon, P., Hansen, I.M., Battisti, A. (2018). Multiplex PCR for detection of plasmid-mediated 
colistin resistance determinants, mcr- 1 , mcr-2, mcr-3, mcr-4 and mcr-5 for surveillance purposes. Eurosurveillance, 23(6), pii $=17-00672$.

\section{https://doi.org/10.2807/1560-7917.ES.2018.23.6.17-00672}

Roer, L., Hansen, F., Stegger, M., Sönksen, U.W., Hasman, H., Hammerum, A.M. (2017). Novel mcr-3 variant, encoding mobile colistin resistance, in an ST131 Escherichia coli isolate from bloodstream infection, Denmark, 2014. Eurosurveillance, $22(31)$, $\mathrm{pii}=30584$.

https://doi.org/10.2807/1560-7917.ES.2017.22.31.30584

Sennati, S., Di Pilato, V., Riccobono, E., Di Maggio, T., Villagran, A.L., Pallecchi, L., Giani, T. (2017). Citrobacter braakii carrying plasmid-borne mcr-1 colistin resistance gene from ready-to-eat food from a market in the Chaco region of Bolivia. Journal of Antimicrobial Chemotherapy, 72(7), 2127-2129.

https://doi.org/10.1093/jac/dkx078

Sun, J., Li, X-P., Yang, R-S., Fang, L-X., Huo, W., Li, SM., Liu, Y-H. (2016). Complete nucleotide sequence of inci2 plasmid co-harboring bla CTX-M-55 and mcr-1. Antimicrobial Agents and Chemotherapy, 60, AAC.00774-16.

https://doi.org/10.1128/AAC.00774-16

Suzuki, S., Ohnishi, M., Kawanishi, M., Akiba, M., Kuroda, M. (2016). Investigation of a plasmid genome database for colistin-resistance gene mcr-1. The Lancet Infectious Diseases, 16(3), 284-285.

https://doi.org/10.1016/S1473-3099(16)00008-6

Tang, Y., Dai, L., Sahin, O., Wu, Z., Liu, M., Zhang, Q. (2017). Emergence of a plasmid-borne multidrug resistance gene $\mathrm{cfr}(\mathrm{C})$ in foodborne pathogen Campylobacter. Journal of Antimicrobial Chemotherapy, 72(6), 1581-1588.

https://doi.org/10.1093/jac/dkx023

Tse, H., Yuen, K.Y. (2016). Dissemination of the mcr-1 colistin resistance gene. The Lancet Infectious Diseases, 16(2), 145-146.

https://doi.org/10.1016/S1473-3099(15)00532-0
Wang, R., Dorp, L., Shaw, L.P., Bradley, P., Wang, Q., Wang, X., Dorai-Schneiders, T. (2018a). The global distribution and spread of the mobilized colistin resistance gene mcr-1. Nature Communications, 9(1), 1179.

https://doi.org/10.1038/s41467-018-03205-Z

Wang, X., Wang, Y., Zhou, Y., Li, J., Yin, W., Wang, S., Zhang, S., Shen, J., Wang Y. (2018b). Emergence of a novel mobile colistin resistance gene, mcr-8, in NDM-producing Klebsiella pneumonia. Emerging Microbes \& Infections, 7(1), 1-9.

https://doi.org/10.1038/s41426-018-0124-Z

Webb, H.E., Granier, S.A., Marault, M., Millemann, Y., den Bakker, H.C., Nightingale, K.K., Loneragan, G.H. (2016). Dissemination of the mcr-1 colistin resistance gene. The Lancet Infectious Diseases, 16(2), 144-145.

https://doi.org/10.1016/S1473-3099(15)00538-1

Xavier, B.B., Lammens, C., Ruhal, R., Kumar-Singh, S., Butaye, P., Goossens, H., Malhotra-Kumar, S. (2016). Identification of a novel plasmid-mediated colistin-resistance gene, mcr-2, in Escherichia coli, Belgium, June 2016. Eurosurveillance, 21(27), pii $=30280$.

https://doi.org/10.2807/1560-7917.ES.2016.21.27.30280

Yang, Y.Q., Li, Y.X., Lei, C.W., Zhang, A,Y., Wang, H.N. (2018). Novel plasmid-mediated colistin resistance gene mcr7.1 in Klebsiella pneumoniae. Journal of Antimicrobial Chemotherapy, 73(7), 1791-1795.

https://doi.org/10.1093/jac/dky111

Yang, Y.Q., Zhang, A.Y., Ma, S,Z., Kong, L.H., Li, Y.X., Liu, J.X., Wang, H.N. (2016). Co-occurrence of mcr-1 and ESBL on a single plasmid in Salmonella enterica. Journal of Antimicrobial Chemotherapy, 71(8), 2336-2338.

https://doi.org/10.1093/jac/dkw243

Yao, X., Doi, Y., Zeng, L., Lv, L., Liu, J.H. (2016). Carbapenem-resistant and colistin-resistant Escherichia coli coproducing NDM-9 and mcr-1. The Lancet Infectious Diseases, 16(3), 288-289.

https://doi.org/10.1016/S1473-3099(16)00057-8 
Ye, H., Li, Y., Li, Z., Gao, R., Zhang, H., Wen, R., Gao, G.F., Hu, Q., Feng, Y. (2016). Diversified mcr-1 harbouring plasmid reservoirs confer resistance to colistin in human gut microbiota. mBio, 7(2), e00177-16.

https://doi.org/10.1128/mBio.00177-16

Yin, W., Li, H., Shen, Y., Liu, Z., Wang, S., Shen, Z., Wang, Y. (2017). Novel plasmid-mediated colistin resistance gene mor-3 in Escherichia coli. mBio, 8(3), e00543-17.

https://doi.org/10.1128/mBio.00543-17
Zeng, K-J., Doi, Y., Pati,I S., Huang, X., Tian, G-B. (2016). Emergence of the plasmid-mediated mcr-1 gene in colistinresistant Enterobacter aerogenes and Enterobacter cloacae. Antimicrobial Agents Chemotherapy, 60, 3862-3863.

https://doi.org/10.1128/AAC.00345-16

Zurfuh, K., Poirel, L., Nordmann, P. (2016). Occurrence of the plasmid-borne mcr-1 colistin resistance gene in ESBLproducing Enterobacteriaceae in river water and imported vegetable samples in Switzerland. Antimicrobial Agents and Chemotherapy, 60(4), 2594-2595.

https://doi.org/10.1128/AAC.00066-16 